доктор філософських наук, доцент

(Житомирський державний університет імені Івана Франка) miller-melnik@ukr.net

ORCID: 0000-0002-5529-8655

\title{
АКТИВІСТСЬКИЙ ПІДХІД ДО ІНТЕРПРЕТАЦІї ВОЛІ У КОНТЕКСТІ СОЦІАЛЬНО- ФІЛОСОФСЬКОЇ МЕТОДОЛОГІЇ АНАЛІЗУ
}

У статті розглянуто еволюиію розуміння волі і вольових процесів у парадигмі мотивістської, регулятивістської й активістської інтерпретацій. Значна увага у дослідженні зосереджена на становленні активістського підходу до розуміння волі у радянській науковій парадигмі. Автором встановлено, щуо значний вплив на тенезу активістського розуміння волі і вольової активності на індивідуальному і суспільному рівнях здійснили праці Ю. Вейнгольда, Л. Корецької, В. Ойгензіхта, А. Підсівної, Ш. Чхартішвілі. Особлива увага у статті зосереджена на аналізі у пострадянській науковій парадигмі (дослідження О. Водолагіна, Л. Гозмана, О. Крижанівської) розуміння соиіальної $i$ політичної волі в ситуачії глобальної транзитивності сучасного суспільства.

Ключові слова: воля, вольові процеси,соичільна активність, суспільство, мотиваційний підхід, регулятивістський підхід, активістський підхід.

Актуальність дослідження. У сучасному глобалізованому світі, де все більше проявляються тенденції нестабільності, транзитивності, нелінійності розвитку соціальних систем, ефективні суспільні перетворення неможливі без формування високого рівня соціальної активності індивіда й суспільства загалом. Інтенсивність діяльності індивіда у соціальному середовищі залежить від його активності як внутрішньої спрямованості на діяльність. У контексті цього важливим є дослідження різних методологічних підходів до розуміння феномену волі як основи соціальної активності.

Розуміння феномена волі на індивідуальному і суспільному рівнях у філософській традиції пройшло декілька етапів. Перший збігається 3 раціоналістичною філософською традицією, в межах якої воля розглядалася як специфічна якість людської свідомості і психіки, як джерело внутрішньої активності людини, яке сприяє ухваленню рішень людини на основі розуму. Воля тлумачилась в такій парадигмі і як складова розуму, що втілює механізми здійснення соціальної активності поза межами бажань і прагнень або всупереч їм. Подібне розуміння вольової активності характерне для філософії Арістотеля, Плотіна, Р. Декарта, Б. Спінози, Т. Гоббса, Дж. Локка, І. Канта, Г. Гегеля. Зокрема визначення ролі розуму й вольового начала у процесі ухвалення суспільно-значущих рішень та роль у цьому процесі моральної й релігійної мотивації стало предметом грунтовного дослідження Г. Гегеля. Другий етап в інтерпретації феномена волі пов'язаний зі становленням філософії волюнтаризму. В іiі межах воля розглядається як основа існування світу загалом і соціального середовища зокрема. У подібному розумінні поняття "воля" вживається для позначення трансцендентальної реальності у філософії Аврелія Августина, Фоми Аквінського, А. Шопенгауера, Ф. Тьонніса, О. Шпенглера, І. Ільїна. У філософії волюнтаризму обгрунтовується субстанційний характер волі, яка у повній мірі постає й основою становлення індивідуальної та суспільної свідомості і, як наслідок, усієї повноти виявів соціальної активності. Саме у такому контексті розглядається поняття "воля до влади" Ф. Ніцше як уособлення прагнення організму до самозбереження та самоствердження. У межах філософії волюнтаризму сформувався й методологічний підхід, за яким воля ототожнювалася з активністю свідомості (А. Шопенгауер, М. Лоський, В. Шмаков, О. Бахтіяров).

У свою чергу і дослідження вольової природи соціальної активності у науковій парадигмі мало суперечливий характер. У радянській матеріалістичній філософії активність в цілому й соціальна активність зокрема тривалий час залишалися "незручними" і незатребуваними об'єктами пізнання. Це було зумовлено тим, що в межах діалектичного матеріалізму джерело діяльності виводилося 3 зовнішніх об’єктивних детермінант. Внутрішні суб'єктивні чинники людської діяльності не вкладалися у матеріалістичну картину світу, адже їх важко було пояснити винятково впливом природної або соціальної необхідності. Відтак, поняття "активність", яке вказувало на іманентні внутрішні начала людської поведінки, увійшло у вітчизняну науку значно пізніше, ніж поняття "діяльність". У зв'язку з цим дослідження проблематики соціальної активності активізувалося лише у 70-80-ті роки ХХ ст. Зокрема, у філософському й соціологічному контекстах активність стала предметом зацікавленості К. АбульхановоїСлавської, Є. Ануфрієва, Г. Ареф'євої, М. Берштейна, В. Біленького. Атрибутивні ознаки, зміст, критерії, механізми, специфіка окремих форм активності стали предметом аналізу Т. Богданова, Т. Лапіної, В. Мордковича, О. Якуби. В українській науковій літературі проблема соціальної активності не стала предметом системного наукового аналізу. Щоправда, деякі іiі аспекти розкриті у працях В. Гавелі, О. Івченка, В. Татенка, М. Стадника, О. Якуби. Незважаючи на значний доробок дослідників у контексті 
вивчення волі й соціальної активності, проблема концептуалізації аналізу волі як основи соціальної активності залишається перспективним об'єктом соціально-філософського аналізу.

Метою дослідження є аналіз активістського підходу до розуміння вольових процесів у контексті соціально-філософської методологічної парадигми.

Виклад основного матеріалу. Якщо в XIX ст. волюнтаризм був одним 3 провідних напрямків в ірраціоналістичній традиції інтерпретації соціально-філософських феноменів, то у ХХ ст. під впливом фрейдизму, марксизму та позитивізму проблематика дослідження волі, вольових процесів, станів і якостей поступово змістилася на маргінес наукового аналізу. Основні здобутки у дослідженні феномена волі в означений період були здійснені у сфері психології, в межах якої сформувалися три основні підходи до тлумачення вольових процесів - мотивістський, регулятивістський та активістський. Згідно 3 мотивістським підходом воля пов'язувалася з моральністю як основою переведення особистісних мотивів на суспільний рівень (І. Сеченов, С. Рубінштейн, Л. Виготський, Д. Узнадзе, В. Іванніков). У контексті мотиваційного підходу до розуміння волі перебуває i виведення Б. Ананьєвим, Л. Божович, С. Рубінштейном, О. Леонтьєвим, Д. Узнадзе та ін. волі і вольових процесів зі сфери бажань і прагнень. Утім мотивацію соціальної активності через пї вольовий, часто ірраціональний характер, доволі важко визначити, адже в деяких випадках складно з'ясувати джерела й рушійні сили соціальної активності. Також слід враховувати й те, що вольова регуляція деяких форм соціальної активності не залежить повністю від мотивації суб'єкта діяльності. Так, мотивація може і не простежуватись в активності митця, який 3 зацікавленістю, не стежачи за часом, займається творчістю. Те саме стосується й матері, яка, не переймаючись небезпекою для себе, кидається на допомогу дитині. Натомість у регулятивістський парадигмі аналізу регулятивна функція волі розглядається як основа соціальної активності. Саме до такого тлумачення волі схилялися М. Басов, М. Бріхцин, Л. Виготський, В. Калін, А. Пуні, П. Рудик, В. Смирнов та ін. Однак, визнаючи значущість висновків вище вказаних дослідників, слід зазначити, що акцентація лише на регулятивній функції волі збіднює ії зміст. Зокрема доволі важко розкрити вольову регуляцію поведінки суб'єкта діяльності без врахування їі мотиваційних і ціннісних аспектів.

Активістський підхід до розуміння вольових процесів сформувався на перетині психології, соціології та соціальної філософії. Він тісно пов'язаний з марксистсько-ленінським розумінням волі як основи активної перетворюючої діяльності. Згідно з активістським підходом, воля постає як основа свідомої діяльності у відповідності з поставленою метою. У такій інтерпретації воля є засобом подолання перешкод у сфері природної і соціальної реальності. У різних дослідженнях, які належать до цього напрямку, виокремлюється один 3 моментів вольового процесу- його свідомий і цілеспрямований характер, опосередкованість волі інтересами й потребами суб'єктів соціальної активності, активізаційний характер волі та ін. Виходячи з різноспрямованості досліджень представників напрямку, у них сформувалися й різні визначення поняття волі.

3 прихильників активістського підходу до інтерпретації волі найбільший інтерес викликають праці Ю. Вейнгольда, Л. Гумільова, О. Крижанівської, Л. Корецької, В. Ойгензіхта, Ш. Чхартішвілі. Цікавою 3 точки зору виявлення вольових засад соціальної активності є концепція пасіонарності Л. Гумільова. Згідно 3 нею, діяльність пасіонарних особистостей як носіїв енергії волі, вольового вчинку є рушійною силою розвитку не тільки окремих етносів, а й суспільства загалом. Аналізуючи механізми етногенезу, дослідник дійшов висновку, що етногенез детермінований наявністю у деяких індивідів незворотного внутрішнього потягу до цілеспрямованої діяльності, тісно пов'язаної зі зміною суспільного чи природного середовища. Більше того, досягнення поставленої мети, часто ефемерної, згубної для самого суб'єкта, уявляється пасіонарію ціннішим за власне життя. Безсумнівно, таке рідкісне явище $є$ відхиленням від видової норми поведінки, адже зазначений імпульс протилежний інстинкту самозбереження [1:252]. В умовах загострення екологічних, політичних, економічних, релігійних проблем їх вирішення в суспільстві залежить від наявності в суспільстві пасіонарних особистостей. В результаті діяльності пасіонаріїв, соціум зазвичай пристосовується до нового середовища, а в деяких випадках відбувається формування нових етносів. Вольовий характер соціальної активності пасіонарія по-різному втілюється на різних етапах етносоціогенезу. Одночасно рівень вольової активності пасіонаріїв залежить від впливу зовнішніх і внутрішніх факторів етнічної самоорганізації. Концепція пасіонарності Л. Гумільова є цікавим напрямком тлумачення феномену вольової активності, однак у ній відкритим залишається питання про джерела і природу пасіонарності.

До позиції розуміння волі як джерела активності схилявся і Ш. Чхартішвілі. На відміну від потреб, які прив'язані до теперішнього часу, воля, на його думку, виключає індивіда 3 моменту плину життя, ставить його вище інтересів моменту теперішнього. Це стосується, насамперед, сфери виявлення безпосередньої активності, де людина перетворюється на суб'єкта суспільних перетворень, стаючи особистістю, яка здатна у різні моменти життя зробити раціонально усвідомлений вибір. Воля покликана слугувати спонукальним механізмом поведінки, який задовольняє зовнішні суспільні вимоги, прийняті суб'єктом [2: 73]. Іншими словами, Ш. Чхартішвілі не розглядав волю як складову частину мотиваційного процесу, а інтерпретував іiі як особливе психічне явище або як здатність особистості. Завдяки цій здатності людина, яка спочатку була 
істотою, що живе лише теперішнім, піднімається до рівня суспільної особистості і стає суб'єктом активної вольової соціально значущої поведінки. Природа активності людини має, на його думку, бінарний характер, одночасно реалізуючи імпульсивну і вольову форму поведінки. 3 таким типом активності ми маємо справу у тих випадках, коли єдина діяльність виникає 3 двох різних за природою джерел, мотивів, цілей [2: 80]. Обгрунтовуючи необхідність відокремлення волі від мотивації, дослідник доводив, що без мотиву вольової поведінки не буває.

Як елемент суб'єктивного фактору некапіталістичного типу розвитку соціальна воля досліджувалася у праці радянського дослідника Ю. Вейнгольда "Некапіталістичний розвиток і соціальна воля" [3]. 3 метою розмежування психологічних інтерпретацій волі дослідник ввів у науковий обіг поняття "соціальна воля" для позначення волі як фактору суспільного розвитку. При цьому він визначив волю як "соціально зумовлений психофізичний стан людини, виражений в ії здатності регулювати й активізувати свою поведінку" [3: 145]. Слушною є й позиція автора, за якою воля є не тільки невід’ємною рисою народних рухів, а й рушійною силою суспільного прогресу. Воля втілюється в активно-спонукальній здатності суб'єкта, пронизує усі типи суспільних відносин, усі форми суспільної свідомості й існує на різних рівнях свідомості. Зазначеній проблематиці присвячена і дисертація А. Підсівної "Суспільна воля, ії місце і роль в житті суспільства" [4], в якій розглядається специфіка виявлення суспільної волі в радянському соціумі, на противагу капіталістичному способу виробництва.

Новий етап дослідження волі як основи соціальної активності розпочинається у 80-ті роки ХХ ст. У 1983 р. вийшли друком дві праці, які справили значний вплив на подальший розвиток соціальнофілософського розуміння волі. Так, у монографії В. Ойгензіхта "Воля і волевиявлення" (Душанбе, 1983) воля розкривається у правовому аспекті. Вона визначається як єдиний психічний регулятивний процес, властивостями якого $є$ свідомість і активність [5:3]. Свідомість, на думку дослідника, ставить безпосередню мету, однак ііі досягнення здійснюється винятково за допомогою вольового начала. Якщо праця В. Ойгензіхта присвячена головним чином виявленню волі у правовій сфері, то дисертація Л. Корецької "Соціальна воля як фактор суспільної життєдіяльності" є одним 3 найбільш цілісних досліджень феномена волі у соціально-філософському контексті. Дослідниця не тільки окреслила методологічні принципи дослідження соціальної, зокрема колективної волі, а й проаналізувала волю колективного суб'єкта, трудового колективу, виділила зміст волі буржуазії [6]. Проте, вказане дослідження не позбавлене й деяких суперечностей. Окрім відвертої ідеологічної спрямованості, у ньому основна увага сконцентрована на аналізі потреб як важливої складової виявлення волі у соціальному середовищі.

Особливої уваги у контексті соціально-філософської методології дослідження волі заслуговує праця російської дослідниці О. Крижанівської "Свобода, воля, влада (філософські проблеми соціальної і політичної волі" (Ростов-на-Дону, 1996). У ній розглянуто взаємозалежність індивідуальної, соціальної і політичної волі, які тлумачаться в історичному і структурному аспектах. Політична воля інтерпретується авторкою як найбільш конкретне і яскраве втілення соціальної волі. Суб'єктами політичної волі дослідниця називає політичних лідерів, політичні еліти, класи, нації, держави, трансдержавні і транснаціональні політичні асоціації. Значна увага в монографії присвячена й дослідженню технологій політичного волевиявлення і патологій політичної волі. Волю О. Крижанівська розглядає у контексті діяльності соціальних суб'єктів як родової характеристики людського буття. Такий підхід дозволив розкрити динаміку волі, виявити закономірності ії розвитку, проаналізувати волю як складову історичного процесу. Дослідниця не тільки осмислює роль вольового фактора у процесі становлення основних суб'єктів соціальної діяльності, значну увагу вона зосереджує й на аналізі морального змісту волі, зв'язку волі, знання і самосвідомості [7:9]. Водночас О. Крижанівська зосередила увагу й на ролі вольового діяльнісного начала як фактора цивілізаційного суспільного прогресу.

Серед небагатьох робіт, в яких досліджуються окремі аспекти політичної волі, слід назвати й дослідження російських авторів Л. Гозмана й О. Шестопала "Політична психологія". У ньому автори стверджують, що "політична воля завбачує здатність піднятися над дрібними особистісними і груповими інтересами на догоду національним. Без політичної волі неможливо вийти за межі політичних стереотипів і подолати інерцію мислення" [8: 190]. Однак, у такому розумінні політична воля, на нашу думку, зводиться лише до ії національного аспекту. Політична воля може бути не тільки способом подолання політичних стереотипів, а й засобом їх вироблення і примусового насадження у суспільно-політичному середовищі.

Достатньо грунтовно проблематика політичної волі висвітлена i в працях Г. Тульчинського i О. Водолагіна. У них основна увага сконцентрована на визначенні теоретико-методологічних підходів до розуміння феномена політичної волі. Значну увагу автори зосередили на дослідженні античної концепції всесвітнього панування, джерел і особливостей християнського волюнтаризму, метафізики волі і влади у філософії Нового часу, субстанційного волюнтаризму А. Шопенгауера та Ф. Ніцше [9: 39]. У своєму історичному існуванні людина, за твердженням О. Водолагіна, відкрита можливостям буття, які ще не стали речами і подіями. I ось ця відкритість, яка проявляється у "невикоріненій спразі людського духу, в станах безпричинного страху, неспокою, тривоги, незадоволення самим собою і світом, вказує на постійну готовність до самовизначення, яку ми і називаємо волею" [10: 3]. За усієї повноти аналізу феномена волі у 
зазначених працях відсутнє визначення сутності політичної волі в історичній ретроспективі та у площині глобалізаційних процесів, що дало б можливість розробити ефективні механізми уникнення маніпуляцій у сфері політичної волі та державного управління.

Проблематика співвідношення вольової й соціальної активності розкрита й у дисертації російського дослідника В. Гопка. У ній зроблена спроба аналізу масової культури як носія надіндивідуальної волі, іiі оцінки 3 позицій філософської антропології. Дослідник доводить, що масова культура є результатом взаємодії надіндивідуальних воль. Під надіндивідуальною волею він розуміє суспільну волю, волю держави, волю корпоративну й глобальну. При цьому різні потоки масової культури здійснюють відповідно не тільки специфічний вплив на вольові якості індивіда, а й детермінують його цілепокладання [11]. В таких умовах масова культура, яка використовується у технологіях управління суспільством, формує як руйнівну, так і творчу індивідуальну й суспільну волю. До суперечливих моментів згаданої роботи можна віднести те, що основна увага у ній зосереджена на дослідженні феномену масової культури, і це робиться лише опосередковано через аналіз проявів волі у соціокультурному середовищі.

Висновки. Загалом, у науковій парадигмі у ХX ст. проблематика дослідження волі не тільки змістилася у сферу психологічних дисциплін, під впливом позитивістських і психоаналітичних методологічних підходів, проблема волі не тільки опинилася на маргінесі наукового інтересу, а й зосередилася переважно у межах експериментальної методології наукового аналізу. Поряд з цим у радянській науковій парадигмі у руслі марксистсько-ленінської ідеологічної парадигми зусилля дослідників були спрямовані переважно на доведення об'єктивного, незалежного від свідомості характеру вольових зусиль. Це призвело до становлення у вітчизняній науковій парадигмі мотиваційного, регулятивістського та активістського підходів до розуміння волі.

Активістський, підхід до інтерпретації волі і вольових процесів остаточно сформувався у другій половині 70-х - 80-х pp. ХХ ст., коли під впливом марксистсько-ленінського розуміння волі як основи активної перетворюючої діяльності прокинувся інтерес до дослідження волі як соціального феномена. У межах активістського підходу воля тлумачиться як основа свідомої діяльності соціального суб'єкта у відповідності з поставленою метою. У такому розумінні вольова активність постає засобом подолання перешкод у сфері природної і соціальної реальності. При цьому основою вольової активності соціального суб'єкта прихильники активістського підходу вважають один 3 моментів вольового процесу - його свідомий цілеспрямований характер, опосередкованість волі інтересами й потребами суб'єктів, активізаційний характер волі та ін.

Вирішальний вплив на становлення активістського розуміння волі і вольової активності на індивідуальному і суспільному рівнях здійснили праці Ю. Вейнгольда, Л. Корецької, В. Ойгензіхта, А. Підсівної, Ш. Чхартішвілі. У пострадянській науковій парадигмі у руслі активістського підходу перебувають дослідження О. Водолагіна, Л. Гозмана, О. Крижанівської, які розглядали соціальну і політичну волю в умовах глобальної транзитивності сучасного суспільства.

\section{СПИСОК ВИКОРИСТАНИХ ДЖЕРЕЛ ТА ЛІТЕРАТУРИ}

1. Гумилев Л. Н. Этногенез и биосфера Земли / Л. Н. Гумилев. - Л. : Изд-во Ленинградского ун-та, 1989. -496 с.

2. Чхартишвили Ш. Н. Проблема воли в психологии / Ш. Н. Чхартишвили // Вопросы психологии. - 1967. № 4. - С. 72-81.

3. Вейнгольд Ю. Ю. Некапиталистическое развитие и социальная воля / Ю. Ю. Вейнгольд. - Фрунзе : Мектеп, 1970. $-335 \mathrm{c}$.

4. Подсевная А. П. Общественная воля, ее место и роль в жизни общества : автореф. дис. на соискание уч. степени канд. филос. наук. : спец. 09.00.01. "Онтология и теория познания" / А. П. Подсевная. - Иркутск, 1973. $-27 \mathrm{c}$

5. Ойгензихт В. А. Воля и волеизъявление (Очерки теории, философия и психологии права) / В. А. Ойгензихт. Душанбе : Дониш, 1983. - 256 с.

6. Корецкая Л. Ф. Социальная воля как фактор общественной жизнедеятельности : автореф. дис. на соискание уч. степени канд. филос. наук : спец. 09.00.01. "Онтология и теория познания" / Л. Ф. Корецкая. - Моск. ин-т нар. хоз-ва им. Г. В. Плеханова. - М., 1983. - 17 с.

7. Крыжановская О А. Свобода, воля, власть (философские проблемы социальной и политической воли)/ О А. Крыжановская. - Ростов-на-Дону : СКНЦ ВШ, 1996. - 163 с.

8. Гозман Л. Я. Политическая психология : [монографія]/ Л. Я. Гозман, Е. Б. Шестопал. - Ростов-на-Дону : Феникс, 1996. - 426 c.

9. Тульчинский Г. Л. Разум, воля, успіх : о философии поступка / Г. Л. Тульчинский. - Л. : Издательство Ленинградского университета, 1990. - 216 с.

10. Водолагин А. В. Онтология политической воли / А. В. Водолагин. - Тверь : Дайджест, 1992. - 110 с.

11. Гопко В. В. Воля в массовой культуре : автореф. дис. на соиск. учен. степ. канд. филос. наук : спец. 09.00.13 "Философия и история религии, философская антропология, философия культуры" / В. В. Гопко ; [Омский гос. пед. университет]. - Омск, 2006. - 18 с. 


\section{REFERENCES (TRASLATED \& TRANSLITERATED)}

1. Gumilev L. N. Etnogenez i biosfera Zemli [Ethnic Genesis and Biosphere of Earth] / L. N. Gumilev. - L. : Izd-vo Leningradskogo un-ta, 1989. - $496 \mathrm{~s}$.

2. Chkhartishvili Sh. N. Problema voli v psikhologii [A Problem of Will is in Psychology] / Sh. N. Chkhartishvili // Voprosy psihologii [Psychology Questions]. - 1967. - № 4. - S. 72-81.

3. Veingold Yu. Yu. Nekapitalisticheskoie razvitie i social'naia volia [Non-Capitalist Development and Social Will]/ Yu. Yu. Veingold. - Frunze : Mektep, 1970. - 335 s.

4. Podsevnaya A. P. Obshchestvennaia volia, ee mesto i rol' v zhizni obshchestva [Public Will, Her Place and Role in Life of Society] : avtoref. dis. na soiskaniie uch. stepeni kand. filos. nauk : spets. 09.00.01. "Ontologiia i teoriia poznaniia". - Irkutsk, 1973. $-27 \mathrm{~s}$.

5. Oigenzikht V. Volia i voleiziavlenie [Will and Expression of Will] / V. Oigenzikht. - Dushanbe : Donish, 1983. $256 \mathrm{~s}$.

6. Koretskaya L. F. Social'naia volia kak faktor obshchestvennoi zhiznedeiatel'nosti [Social Will as Factor of Public Vital Functions] : avtoref. dis. na soiskaniie uch. stepeni kand. filos. nauk : spets. : 09.00.01. "Ontologiia i teoriia poznaniia". - M., 1983. - $17 \mathrm{~s}$.

7. Kryzhanovskaya O. A. Svoboda, volia, vlast' [Freedom, Will, Power] / O. A. Kryzhanovskaya. - Rostov-na-Donu : SKNC VSH, 1996. - $163 \mathrm{~s}$.

8. Gozman L. Ya. Politicheskaia psikhologiia [Political Psychology] : [monografiia]. - Rostov-na-Donu : Feniks, 1996. $426 \mathrm{~s}$.

9. Tul'chinskii G. L. Razum, volia, uspekh : o filosofii postupka [Reason, Will, Success : about Philosophy of Act]. - L. : Izdatel'stvo Leningradskogo universiteta, 1990. - $216 \mathrm{~s}$.

10. Vodolagin A. V. Ontologiia politicheskoi voli [Ontology of Political Will] / A. V. Vodolagin. - Tver' : Daidzhest, 1992. $-110 \mathrm{~s}$

11. Gopko V. V. Volia v massovoi kul'ture [Will Is in a Mass Culture] : avtoref. dis. na soisk. uchen. step. kand. filos. nauk : 09.00.13 "Filosofiia i istoriia religii, filosofskaia antropologiia, filosofiia kul'tury" / V. V.Gopko ; [Omskii gos. ped. universitet]. - Omsk, 2006. $-18 \mathrm{~s}$.

\section{Ковтун Н. М. Активистский подход к интерпретации воли в контексте социально-философской} методологии анализа.

В статье рассмотрено эволючию понимания воли и волевых процессов в парадигме мотивистской, регулятивистской и активистской интерпретаций. Особое внимание в исследовании посвящено анализу становления активистского подхода к пониманию воли в советской научной парадигме. Автором доказано, что значительное влияние на генезис активистского понимания воли и волевой активности на индивидуальном и общественном уровнях имели работы Ю. Вейнгольда, Л. Кореикой, В. Ойгензихта, А. Подсевной, Ш. Чхартишвили. Значительное внимания в статье сконцентрировано на изучении в постсоветской научной парадигме (исследования А. Водолагина, Л. Гозмана, О. Крыжановской) понимания сочииальной и политической воли в условиях глобальной транзитивности современного общества.

Ключевые слова: воля, волевые прочессы, сочииальная активность, общество, мотивационный подход, регуляциионный подход, активистский подход.

\section{Kovtun N. M. Activist Approach to Will Interpretation in the Context of Social and Philosophical Methodology of Analysis.}

In the article evolution of will and volitional processes comprehension in motivational, regulative and activist paradigms is observed. In the research work much attention is paid to formation of activist approach to will comprehension in soviet scientific paradigm. Activist approach which is connected with Marxist-Leninist comprehension of will as basis of active transforming activity was formed at the intersection of psychology, sociology and social philosophy. Within activist approach will is interpreted as the basis of conscious activity of a social subject that is being done in accordance with the realization of the goal. In such an interpretation, will and volitional activity appear to be the means to overcome obstacles in the sphere of natural and social reality. At the same time supporters of an activist approach consider one of the elements of the volitional process i.e. its conscious and purposeful character, mediation of the will of the interests and needs of the subject, activating character of will etc to be the basis of the volitional activity of the social subject. It is stated by the author that significant influence on the genesis of the activist comprehension of will and volitional activity was made by Yu. Weinhold, L. Koretska,

V. Ojgenziht, A. Pidsivna, Sh. Chkhartishvili. In the article post soviet scientific paradigm analysis of social and political will comprehension in a situation of global transitivity of modern society is emphasized (research works of O. Vodolagin, L. Gozman, O. Kryzhanivska).

Key words: will, volitional processes, social activity, society, motivational approach, regulative approach, activist approach. 